\title{
Cloning and expression of chicken 20-hydroxysteroid dehydrogenase
}

\author{
J Bryndová, P Klusoňová, M Kučka, K Mazancová-Vagnerová, I Mikšík and J Pácha
}

Institute of Physiology, Czech Academy of Sciences, Vídeňská 1083, CZ-142 20 Prague 4-Krč, Czech Republic

(Requests for offprints should be addressed to J Pácha; Email: pacha@biomed.cas.cz)

\begin{abstract}
The ligand specificity and activation of steroid receptors depend considerably on the enzymatic activities involved in local pre-receptor synthesis and the metabolism of the steroids. Several enzymes in particular, steroid dehydrogenases have been shown to participate in this process. Here we report the isolation of 20-hydroxysteroid dehydrogenase (ch20HSD) cDNA from chicken intestine and the distribution of ch20HSD mRNA and 20-reductase activity in various avian tissues. Using a reverse transcription PCR and comparison with the known sequences of mammalian $20 \beta \mathrm{HSDs}$, we have isolated a new ch20HSD cDNA. This cDNA predicted 276 amino acid residues that shared about $75 \%$ homology with mammalian $20 \beta H S D$. Sequences specific to the short-chain dehydrogenase/reductase superfamily (SDR) were found, the $G / y-X-X-$ $X$-Gly-X-Gly cofactor-binding motif (residues 11-17) and the catalytic activity motif Tyr-X-X-X-Lys (residues 193-197). The cDNA coding for ch20HSD was expressed in Escherichia coli by placing it under isopropylthiogalactoside (IPTG) inducible control. Both the IPTG cells of $E$. coli and the isolated recombinant protein reduced progesterone to 20-dihydroprogesterone, corticosterone to 20-dihydrocorticosterone and $5 \alpha$-dihydrotestosterone to its 3-ol derivative. The 20-reductase and 3 -reductase activities of ch20HSD catalyzed both $3 \alpha / \beta$ - and $20 \alpha / 20 \beta$-epimers. The mRNA transcripts of ch20HSD were found in the kidney, colon, and testes; weaker expression was also found in the heart, ovaries, oviduct, brain, liver, and ileum. 20-Reductase activity has been proven in tissue slices of kidney, colon, ileum, liver, oviduct, testis, and ovary; whereas the activity was nearly absent in the heart and brain. A similar distribution of 20-reductase activity was found in tissue homogenates measured under $V_{\max }$ conditions. These results suggest that chicken 20HSD is the latest member of the SDR superfamily to be found, is expressed in many avian tissues and whose precise role remains to be determined.
\end{abstract}

Journal of Molecular Endocrinology (2006) 37, 453-462

\section{Introduction}

Hydroxysteroid dehydrogenases (HSDs) are enzymes that play an important role in the biosynthesis and inactivation of steroid hormones. Due to their oxidase and reductase activities, they catalyze the interconversion of biologically active hormones and their less active or inactive derivatives and thus regulate the local concentration of steroid ligands and the transcription of corresponding genes (Penning 1997). HSDs catalyze the stereospecific and reversible conversion of hydroxyl and carbonyl groups at the $\mathrm{C}_{3-}, \mathrm{C}_{11^{-}}, \mathrm{C}_{17^{-}}$, and $\mathrm{C}_{20^{-}}$ positions and belong to two distinct protein superfamilies, short-chain dehydrogenases (SDR) and aldoketo reductases (AKR; Jörnvall et al. 1995, Penning 1997). One of these enzymes is 20ß-hydroxysteroid dehydrogenase (20ßHSD) that was originally found in fish ovaries (Nagahama \& Adachi 1985) and in pig neonatal testis (Nakajin et al. 1988a, Ohno et al. 1992). In addition to being present in pig testicular tissue where it may regulate hormone concentration during development (Ohno et al. 1992), later studies revealed that this enzyme is expressed in many other porcine tissues, including the kidney, liver, heart, lung, and brain (Kobayashi et al. 1996) but the role of 20ßHSD is still ill-defined. Tanaka et al. (1992) showed that porcine 20ßHSD is a cytosolic enzyme that belongs to the SDR superfamily.

We have reported that 20HSD activity in chicken intestine is co-localized with 11ß-hydroxysteroid dehydrogenase (11ßHSD) activity and demonstrated that 20HSD plays a role in modulating the potency of glucocorticoids to stimulate intestinal $\mathrm{Na}^{+}$transport (Vylitová et al. 1998, Mazancová et al. 2005). It has been suggested that the reduction of corticosterone by 20HSD might be an alternative system to the oxidation of this steroid via $11 \beta \mathrm{HSD}$ and thus 20HSD might facilitate aldosterone binding to mineralocorticoid receptors. In agreement with this, 20-dihydrocorticosterone does not possess any affinity for avian aldosterone receptors (DiBattista et al. 1989) and neither 20-dihydrocorticostetone nor 11-dehydro-20-dihydrocorticosterone is able to induce $\mathrm{Na}^{+}$transport in chicken intestine (Mazancová et al. 2005). In addition, avian 20HSD might not only be involved in corticosterone/cortisol, but also in progesterone metabolism, similar to 20HSDs in mammals 
(Penning 1997, Quinkler et al. 1999). The presence of both 20HSD and 11ßHSD also implies that the functional coupling of $11 \beta$-oxidation followed by 20-reduction might amplify the effect of steroid dehydrogenases (Mercer \& Krozowski 1992).

In this study, we report the isolation of cDNA encoding 20HSD from chicken intestine, its overexpression in Escherichia coli, and the distribution of 20HSD mRNA and enzyme activities in various tissues.

\section{Materials and methods}

\section{Animals}

Experiments were performed on Brown Leghorn chickens obtained from the hatchery of the Institute of Molecular Genetics (Czech Acad. Sci., Prague). They were raised under controlled conditions (12 h light: $12 \mathrm{~h}$ darkness period), fed a commercial poultry diet, and had free access to water. The chickens were killed by decapitation and various tissues used for RNA extraction were quickly removed. To identify the expression of steroid dehydrogenase activity in oviduct, some chickens were treated with estrogens because this organ is extremely sensitive to female hormones that induce the differentiation and proliferation of oviduct cells (Dougherty \& Sanders 2005). In this experiment, the females received a daily s.c. injection of $2 \mathrm{mg}$ diethylstilbesterol (DES) per $\mathrm{kg}$ in polypropylene glycol for 7 days starting from day 22. The animal protocol was approved by the Institutional Animal Care Committee.

\section{HSD cloning strategy}

Based on a comparison of the high sequence homology among the known sequences of 20ßHSD (EC $1 \cdot 1 \cdot 1 \cdot 184$ ) in other vertebrates (human, pig, mouse, rat, rabbit, some teleosts), the predicted mRNA sequence of this enzyme in chickens was constructed using the program CLUSTAL W. Briefly, the known sequences were used to search chicken EST (expressed sequence tags) in the free internet National Center for Biotechnology Information (NCBI) database for cDNA fragments with the highest similarity. The fragments found were used to further search the database for other overlapping fragments and thus elongate the sequence. The generated sequence of more than $1200 \mathrm{bp}$ was searched for as an open reading frame by the Basic Local Alignment Search Tool. Based on the sequence of putative ch20HSD, the open reading frame (ORF)specific forward $\left(5^{\prime} \rightarrow 3^{\prime}\right.$ CGCTAGGGAGTGCGGGAAGGT) and reverse primers $\left(5^{\prime} \rightarrow 3^{\prime}\right.$ GCCACTTGCAAGGGTCCACAGA) were designed by the program Lasergene (DNASTAR, Madison, WI, USA) and used in a PCR to obtain the ch20HSD amplicon. The PCR mixture contained $2.5 \mathrm{U}$ platinum tag polymerase, 20 pmol each of the sense and antisense primers, $200 \mu \mathrm{M}$ dNTPs, $50 \mathrm{mM} \mathrm{KCl}, 15 \mathrm{mM}$ Tris-HCl, $0.5 \mathrm{mM} \mathrm{MgCl}$, and $1 \mu \mathrm{l}$ chicken cDNA. Chicken cDNA was prepared from RNA isolated from the ileum by Trisol (Invitrogene) and reverse transcripted using anchorage oligo $(\mathrm{dT})$ primers (Sigma) and Moloney murine leukemia virus (M-MLV) reverse transcriptase (Invitrogene) according to the manufacturer's instructions. Ileal cDNA was used because we have recently demonstrated 20HSD activity in this tissue (Mazancová et al. 2005).

All PCR products were separated on $1.5 \%$ agarose gel and isolated using a GenElute Gel extraction kit (Sigma). Subsequently, the isolated cDNA fragment was inserted into pGEM Easy Vector System (JM 109 competent cells; Promega), the plasmid DNA was purified with a QIAprep Spin Miniprep kit (Qiagen) and sequenced by the ABI PRISM 3100 DNA sequencer in Academy of Sciences Sequencing Facility.

\section{Production and purification of ch20HSD recombinant protein}

To produce the ch20HSD recombinant protein, two specific primers were designed close to the ORF region of ch20HSD. The protein was cloned and expressed using the Champion pET SUMO Protein Expression System (Invitrogene) according to the manufacturer's instructions. Briefly, the purified PCR product from chicken ileal cDNA was inserted into the bacterial expression vector $\mathrm{pET}$ SUMO and transformed to One Shot Match 1-T1 Chemically Competent E. coli. We extracted the plasmid from cells possessing kanamycine resistance and after confirming the proper sequence orientation by nucleotide sequence analysis, the plasmid was transformed to One Shot BL21 (DE3) Chemically Competent E. coli. The same cells transformed with the $\mathrm{pET}$ SUMO/CAT plasmid were used as a positive control. This plasmid allows expression of N-terminally tagged chloramphenicol acetyl transferase (CAT).

The soluble ch20HSD recombinant protein was prepared in cells cultivated in bacterial growth medium (LB medium) containing $50 \mu \mathrm{g} / \mathrm{ml}$ kanamycine. After the cells reached a cell density of $0 \cdot 5$, isopropyl-1-thio- $\beta$-Dgalactopyrasonide ( $1 \mathrm{mM}$; IPTG) was added to induce protein synthesis and the cells were incubated for another $6 \mathrm{~h}$ at $37^{\circ} \mathrm{C}$. The cells were then harvested, and lysed by sonication, freezing, and thawing. The purified protein was prepared according to the manufacturer's instruction using a Ni-CTA HC RESIN (Sigma). Pure protein was eluted by $250 \mathrm{mM}$ imidazole, $300 \mathrm{mM} \mathrm{NaCl}$, and $50 \mathrm{mM}$ sodium phosphate ( $\mathrm{pH}$ 8.0). Fractions containing purified ch20HSD were pooled and the purity and molecular weight of the protein was verified by $12 \%$ SDS-PAGE, fixed, and stained using the standard Coomassie blue protocol. 


\section{Assays of enzymatic activities}

Determination of the activity of recombinant ch20HSD was performed in a cell suspension of intact $E$. coliand that of native ch20HSD in tissue slices and homogenates using a steroid assay. The suspension of $E$. coli or the purified recombinant protein of ch20HSD was utilized to determine the enzyme activity, its stereospecificity, and substrate specificity. The enzyme assay was conducted in incubation buffer $(100 \mathrm{mM} \mathrm{KCl} ; 50 \mathrm{mM}$ Tris- $\mathrm{HCl}$ $(\mathrm{pH} 8 \cdot 5)$ ) containing $0 \cdot 8 \mathrm{mM} \mathrm{NADPH}$ and $\left[1,2,6,7-{ }^{3} \mathrm{H}\right]$ corticosterone, $\left[1,2,6,7-{ }_{-}^{3} \mathrm{H}\right]$ progesterone, $5 \alpha$-dihydro $\left[1,2,4,6,7-{ }^{3} \mathrm{H}\right]$ testosterone, or $\left[1,2,6,7-{ }^{3} \mathrm{H}\right]$ aldosterone $(65 \mathrm{nM})$. The reaction was stopped by cooling and the steroids extracted from the incubation medium using Sep-Pak cartridges. The SUMO/CAT protein was used as a negative control and showed no steroid activity. The incubation times were selected to ensure that the velocities of the individual reactions would be linear. To identify the stereospecificity of ch20HSD, progesterone instead of corticosterone was used because $\alpha$-epimer of 20-dihydrocorticosterone was not available in the market. The conversion of androstanolone ( $5 \alpha$-dihydrotestosterone) was studied because some 20HSDs also show $3 \alpha / 3 \beta-$ hydroxysteroid dehydrogenase activity.

The distribution of ch20HSD activity in chickens was determined in tissue slices and homogenates of the kidney, liver, brain, heart, ileum, testes, ovaries, and oviduct using an enzyme assay carried out as previously described (Mazancová et al. 2005) with some modifications. Briefly, tissue slices $(<1 \mathrm{~mm}$ thick; $100 \mathrm{mg})$ were incubated in Dulbecco's Modified Eagle's Medium (DMEM) containing $\left[{ }^{3} \mathrm{H}\right]$ corticosterone $(17 \mathrm{nM})$ in the presence of $95 \% \mathrm{O}_{2} / 5 \% \mathrm{CO}_{2}$ at $37^{\circ} \mathrm{C}$. Tissue homogenates were prepared by homogenization $(1: 9, \mathrm{w} / \mathrm{v})$ in an ice-cold buffer containing $200 \mathrm{mM}$ sucrose and $10 \mathrm{mM}$ Tris-HCl (pH 8.5) with a Polytron homogenizer. The homogenates were centrifuged at $1000 \mathrm{~g}$ for $10 \mathrm{~min}$ and the supernatant was assayed for protein concentration using the Coomassie blue method. The conversion of corticosterone was assayed in tubes containing the buffer (100 mM KCl, $50 \mathrm{mM}$ Tris-HCl (pH 8.5)), cosubstrate NADPH or NADH $(0.4 \mathrm{mM})$, homogenate $(0.05-1 \mathrm{mg}$ protein depending on the tissue), and $\left[{ }^{3} \mathrm{H}\right]$ corticosterone $(25 \mathrm{nM})$. To remove the oxidized cosubstrate produced by 20HSD from the reaction mixture, the enzyme activity was determined in the presence of $2 \mathrm{U}$ glucose-6-phosphate dehydrogenase purified from baker's yeast (Sigma) and $1 \mathrm{mM}$ glucose-6-phosphate (Agarwal et al. 1990). The reactions were stopped by cooling and the steroids extracted using Sep-Pak cartridges. All assays were carried out in triplicate.

\section{Analysis of steroids}

The analysis of the steroids was performed by HPLC using an Agilent 1100 system (Agilent, Palo Alto, CA, USA) consisting of a degasser, a binary pump, an autosampler, a thermostated column compartment, a multiwavelength detector, and a radioactivity detector (Radiomatic 150TR; Canberra Packard, Meriden, CT, USA) with a flow cell (flow rate of scintillation cocktail/mobile phase was 3:1). The reduction product of corticosterone (4-pregnen11ß,21-diol-3,20-dione) was detected according to a previously described procedure (Vylitová et al. 1998, Mazancová et al. 2005). Although we were unable to

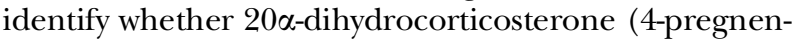
$11 \beta, 20 \alpha, 21$-triol-3-one) and 20 $\beta$-dihydrocorticosterone (4-pregnen-11 $\beta, 20 \beta, 21$-triol-3-one) co-elute, we have seen in all runs only two peaks of radioactivity that co-chromatographed with corticosterone and $20 \beta$ dihydrocorticosterone.

Progesterone (4-pregnen-3,20-dione) derivatives 20 $\alpha$ and $20 \beta$-dihydroprogesterone (4-pregnen-20 $\alpha$-ol-3-one; 4-pregnen-20 $\beta$-ol-3-one) were separated on the Zorbax Eclipse XDB-C18 column $(150 \times 4.6 \mathrm{~mm}$ I.D., $5 \mu \mathrm{m}$, Rockland Technologies (Agilent)). A $20 \mu$ sample was injected and elution was achieved by a linear gradient between mobile phases A (water) and B (acetonitrile: tetrahydrofuran:methanol 50:20:30, v/v/v). Gradient started from $42 \%$ B to $60 \% \mathrm{~B}$ at $20 \mathrm{~min}$ with flow rate $1 \mathrm{ml} / \mathrm{min}$, then the column was eluted with $100 \% \mathrm{~B}$ for $5 \mathrm{~min}$ at elution flow $1 \mathrm{ml} / \mathrm{min}$. Equilibration before the next run was achieved by $10 \mathrm{~min}$ washing with buffer A. Column temperature was held at $30{ }^{\circ} \mathrm{C}$. Detection was made at $254 \mathrm{~nm}$ (standards) or by radioactivity detector (samples).

Analysis of androstanolone ( $5 \alpha$-androstan-17 $\beta$-ol3 -one) derivatives ( $5 \alpha$-androstan-3 $\alpha, 17 \beta$-diol; $5 \alpha$ androstan-3 $\beta, 17 \beta$-diol) was carried out on the Zorbax Eclipse XDB-C18 column $(150 \times 4.6 \mathrm{~mm}$ I.D., $5 \mu \mathrm{m}$, Rockland Technologies (Hewlett-Packard)). A $20 \mu \mathrm{l}$ sample was injected and elution was achieved by a linear gradient between mobile phases A (water) and B (methanol). Gradient started from $42 \%$ B to $62 \%$ B at $5 \mathrm{~min}$ and the following gradient was from $62 \% \mathrm{~B}$ to $100 \% \mathrm{~B}$ at next $15 \mathrm{~min}$ with flow rate $1 \mathrm{ml} / \mathrm{min}$, then the column was eluted with $100 \% \mathrm{~B}$ for $5 \mathrm{~min}$ at elution flow $1 \mathrm{ml} / \mathrm{min}$. Equilibration before the next run was achieved by $10 \mathrm{~min}$ washing with buffer $\mathrm{A}$. Column temperature was held at $30^{\circ} \mathrm{C}$. Detection was made by mass spectrometry (standards) or radioactivity detector (samples). Mass spectrometric instrument was MSD-Trap XCT Ultra (Agilent). There was used atmospheric pressure ionization-electrospray ionization at positive mode. Operating conditions were determined as follows: drying gas $\left(\mathrm{N}_{2}\right)$, $12 \mathrm{l} / \mathrm{min}$; drying gas temperature, $350^{\circ} \mathrm{C}$; nebulizator pressure, $55 \mathrm{psi}$; and capillary voltage, $3500 \mathrm{~V}$; ions were observed at mass range $\mathrm{m} / z$ 100-400. Selected steroids were monitored by extracted ion chromatogram of previously selected ions (i.e. 275, 291, and $257 \mathrm{~m} / \mathrm{z}$ ). 


\section{Analysis of ch20HSD mRNA expression levels}

The tissue distribution of ch20HSD mRNA was studied by real-time RT-PCR. The total RNA $(1 \cdot 3-1 \cdot 8 \mu \mathrm{g})$ from various tissues was reversed transcribed using oligo $(\mathrm{dT})$ primers. The cDNA products were quantified for ch20HSD and $\beta$-actin with a LightCycler-Fast Start DNA Master SYBR Green I kit (Roche) and a LightCycler instrument. The primers used for ch20HSD were: forward AGGGCTGCATCCACTCTTCC and reverse TTTGGCCAACCTTCTTTCTC; and for $\beta$-actin: forward TGATATTGCTGCGCTCGTTGTTGA and reverse CATGGCTGGGGTGTTGAAGGTCTC. PCR was performed in a total volume of $10 \mu \mathrm{l}$ containing $1 \mu \mathrm{l}$ of tenfold diluted cDNA; $4 \mathrm{mM} \mathrm{MgCl}_{2} ; 0.5 \mu \mathrm{M}$ of each primer and the PCR mix $(1 \times)$. The LightCycler was programmed as follows: pre-incubation and denaturation of the template cDNA for $10 \mathrm{~min}$ at $95^{\circ} \mathrm{C}$, followed by 45 cycles of amplification: $95^{\circ} \mathrm{C}$ for $15 \mathrm{~s}$, followed by $56^{\circ} \mathrm{C}$ for $10 \mathrm{~s}$ (ch20HSD) or $64{ }^{\circ} \mathrm{C}$ for $10 \mathrm{~s}$ ( $\beta$-actin), and then $72^{\circ} \mathrm{C}$ for $17 \mathrm{~s}$ (ch20HSD) or $16 \mathrm{~s}$ ( $\beta$-actin). For quantification, we prepared standard curves for both pairs of primers from serial dilutions of chicken cDNA. The results were calculated as the relative expression of ch20HSD mRNA to $\beta$-actin mRNA. Samples for real-time PCR experiments were measured on two occasions for each sample.

\section{Results}

\section{Chicken ch20HSD cDNA sequence and the deduced primary structure}

The cloning strategy to identify a putative ch20HSD was based on a procedure that searched the free internet chicken EST database for the cDNA fragments with the highest similarity to the conserved domains of known vertebrate $20 \beta$ HSDs. The fragments found were then used to further search the database for other overlapping fragments and thus elongate the sequence. Figure 1 shows a comparison of the deduced amino acid sequence of the ch20HSD with other steroid dehydrogenases. Similar to other members of SDR family (Jörnvall et al. 1995), the deduced ch20HSD protein contains the wellconserved putative cosubstrate-binding domain (AAs 1034) with the well-conserved motif Gly-X-X-X-Gly-X-Gly. Similarly, the triad Tyr, Lys, and Ser can also be found in ch20HSD, including the highly conserved Tyr-X-X-X-Lys segment assigned to the catalytic center. The deduced ch20HSD amino acid sequence exhibits 72-78\% homologies with human, pig, rat, mouse, and rabbit 20ßHSD, and a little less with teleosts, zebrafish (Danio rerio), rainbow trout (Oncorhynchus mykiss), and ayu fish (Plecoglossus altivelis; Table 1). This process resulted in the generation of a $930 \mathrm{bp}$ sequence. The sequence was verified in vitro by cloning in $E$. coli and then published in the GenBank nucleotide sequence database with the accession number NM001030795. The ORF encodes a protein of 276 amino acid residues with a calculated molecular mass of $30 \cdot 25 \mathrm{kDa}$.

\section{Recombinant expression of ch20HSD in E. coli}

To confirm that the cDNA encodes active 20HSD, we cloned the ORF of putative 20HSD into the pET SUMO plasmid. As shown in Fig. 2, the transfection of E. coli with the plasmid construct resulted in conversion of corticosterone to 20-dihydrocorticosterone, but E. coli transfected with the plasmid without ch20HSD did not show any 20-reductase activity. Subsequent overexpression resulted in a SUMO/ch20HSD fusion protein. This protein was purified by chromatography and the purity of the recombinant protein was determined by SDS-PAGE (Fig. 3). The molecular mass of the recombinant protein shown in Fig. 3 corresponds with the sum of the molecular mass of the SUMO protein $(11 \mathrm{kDa})$ and that predicted for ch20HSD $(30 \cdot 25 \mathrm{kDa})$.

The HPLC profile of progesterone incubated with the recombinant protein exhibited two metabolites, $20 \alpha$ and 20 $\beta$-dihydrotestosterone (Fig. 4), but catalyzed the production of $\beta$-epimer more efficiently $(27.9 \pm$ $2.5 \mathrm{pmol} / \mathrm{h}$ per $\mathrm{mg}$ protein; $n=6$ ) than the $\alpha$-epimer $(11 \cdot 5 \pm 1 \cdot 0 \mathrm{pmol} / \mathrm{h}$ per $\mathrm{mg}$ protein; $n=6)$. The ability of ch20HSD to reduce progesterone $(39 \cdot 4 \pm 3.5 \mathrm{pmol} / \mathrm{h}$ per mg protein; $n=6$ ) was very similar to that of reduction of corticosterone to 20-dihydrocorticosterone $(38.9 \pm 0.4 \mathrm{pmol} / \mathrm{h}$ per $\mathrm{mg}$ protein; $n=7)$. Since there have been several reports on bifunctional hydroxysteroid dehydrogenases having 20HSD and 3HSD activities (Ohno et al. 1991, Penning 2003), we further investigated the catalytic activity of ch20HSD for the reduction of the oxo group at position $\mathrm{C}_{3}$. When androstanolone was incubated with ch20HSD in the presence of NADPH, two peaks corresponding to the reduced products of androstanolone, $5 \alpha$-androstan$3 \alpha, 17 \beta$-diol and $5 \alpha$-androstan- $3 \beta, 17 \beta$-diol, were identified (Fig. 5) and this reduction at $\mathrm{C}_{3}$ was more efficient ( $\alpha$-epimer, $83.3 \pm 2.5 \mathrm{pmol} / \mathrm{h}$ per $\mathrm{mg}$ protein, $n=6$; $\beta$-epimer, $104 \cdot 8 \pm 11.9 \mathrm{pmol} / \mathrm{h}$ per $\mathrm{mg}$ protein, $n=6$ ) than the reduction at $\mathrm{C}_{20}$ (see above). When aldosterone was incubated with ch20HSD in the presence of NADPH, no metabolites were identified.

As shown in Fig. 6, ch20HSD efficiently catalyzed the reduction of substrate using NADPH as cosubstrate but no conversion was found with $\mathrm{NADH}$.

\section{Tissue distribution of ch20HSD mRNA and activity}

Using specific primers for ch20HSD, we determined the expression levels of ch20HSD mRNA in various tissues. As can be seen in Fig. 7, RT-PCR revealed the highest level of expression in the kidney, colon, and 


Human
Orangutan
Pig
Rabbit
Rat
Mouse
Chicken
Rainbow trout
Ayu fish
Zebrafish

Human
Orangutan
Pig
Rabbit
Rat
Mouse
Chicken
Rainbow trout
Ayu fish
Zebrafish

Human
Orangutan
Pig
Rabbit
Rat
Mouse
Chicken
Rainbow trout
Ayu fish
Zebrafish

Human
Orangutan
Pig
Rabbit
Rat
Mouse
Chicken
Rainbow trout
Ayu fish
Zebrafish

Human
Orangutan
Pig
Rabbit
Rat
Mouse
Chicken
Rainbow trout
Ayu fish
Zebrafish

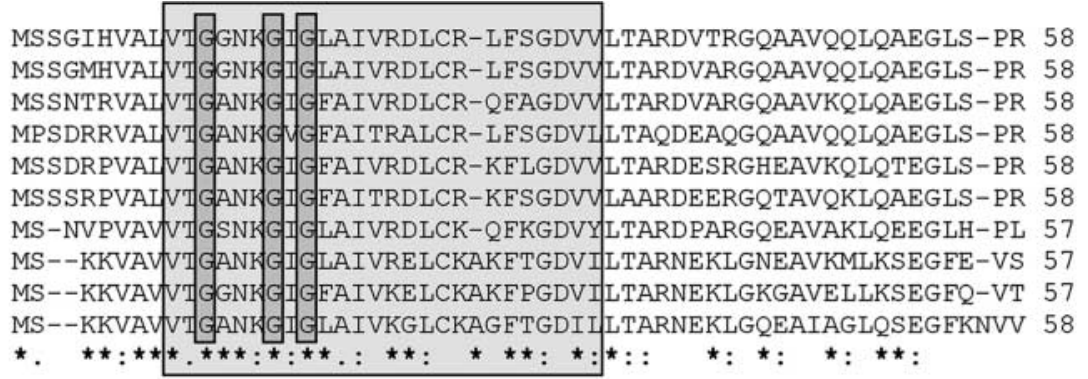

FHQLDIDDLQS IRALRDFLRKEYGGLDVLVNNAGIAFKVADPT PFHIQAEVTMKTNFFGT 118 FHQLDIDDLQS IRALRDFLRKEYGGLDVLVNNAGIAFKVADPT PFHIQAEVTMKTNFFGT 118 FHQLDI IDLQS IRALCDFLRKEYGGLDVLVNNAAIAFQLDNPT PFHIQAELTMKTNFMGT 118 FHQLDITDLQS IRALRDFLRRAYGGLNVLVNNAVIAFKMEDTTPFHIQAEVTMKTNFDGT 118 FHQLDIDNPQS IRALRDFLLQEYGGLNVLVNNAGIAFKVVDPT PFHIQAEVTMKTNFFGT 118 FHQLDIDNPQS IRALRDFLLKEYGGLDVLVNKAGIAFKVNDDT PFHIQAEVTMETNFFGT 118 FHQLDIDDLQS IKVLRDFLKEKYGGLNVLVNNAGIAFKVSDRTPFAVQAEVTLKTNFFGT 117 YHHLDICDQGSAKQLSNFLQKTYGGLDVLINNAGMAFKNDATETFGEQAEVTMRTNFWGT 117 FQHLDICDQGSAVKLRDFLQNTYGGLDVLVNNAGIAFKNDATEPFGEQAEVTMRTNEWGT 117 FHQLDICDQGSCMKLKKFLEEKYGGLDVLINNAGIAFKNAATEPFGEQAEVTMRTNFWGT 118

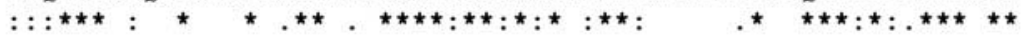

RDVCTELLPLIKPQGRVVNVSSIMSVRALKSCSPELQQKFRSETITEEELVGLMNKFVED 178 RDVCTELLPLIKPQGRVVNVSSIMSVRALKSCSPELQQKFRSETITEEELVGLMNKFVED 178 RNVCTELLPLIKPQGRVVNVSSTEGVRALNECSPELQQKFKSETITEEELVGLMNKFVED 178 RDVCTELLPLMRPGGRVVNVS SMTCLRALKSCSPELQQKFRSETITEEELVGLMKKFVED 178 QDVCKELLPI IKPQGRVVNVSSSVSLRALKSCSPELQQKFRSET ITEEELVGLMNKFIED 178 RDVCKE LLPLIKPQGRVVNVSSMVS LRALKNCRLELQQKERSETITEEELVGLMNKFVED 178 RNICTELLPLIKPYGRVVNVSSMVS ISALGGCSQELQKKFRSDTITEDELVELMTKFVED 177 LWVCHALLPLLRPNARVVNVSSFVSKKALDTCSPQLQAKFRDTELSEEELCLLMGQFVIA 177 LWVSHALIPILRPNARVVNVSSFVSKRALDQCSPQLQAKFRDPKLTEEELCGLMGEFVTA 177 LWACHALLPILRANARVVNVSSFVSKKSLDQCSAELQAKFRNKDLSEEELCLLMGEFVQD 178

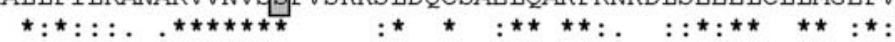

TKKGVHQKEGWPSSA $/$ GVTRIGVTVLSRIHARKLSEQRKGDKILLNACCPGWVRTDMAGP 238 TKKGVHQKEGWPSSA Y GVI I I GVTVLSR I HARKLSEQRKGDRILLNACCPGWVRTDMAGP 238 TKNGVHRKEGWSDST Y GVT I I GVSVLSRIYARKLREQRAGDKILLNACCPGWVRTDMGGP 238 TKKGVHQTEGWPDTA Y GVT KMGVTVLSRIQARHLSEHRGGDKI LVNACCPGWVRTDMGGP 238 AKKGVHAKEGWPNSA Y GVT K I GVTVLSRI YARKLNEERREDKILLNACCPGWVRTDMAGP 238 TKKGVHAEEGWPNSA Y GVT K IGVTVLSRI LARKLNEQRREDKILLNACCPGWVRTDMAGP 238 TKKSVHEKEGWPNTA Y GV W I IVTVLSRIQARMLNEKRKGDHI LLNACCPGWVRTDMAGP 237 AQQGNHQAQGWPNTA Y GT I I IGVTVLSRIQAHYLTKTRAADGILLNACCPGWVRTDMAGS 237 AQNGSHQAEGWPNTA Y GT I I I GATVLSMIQARELTKTRSGDGI LLNACCPGWVRTDMAGD 237 AQAGDHSAKGWPNTA Y GT I I IGVTVLSRIQARVLNETRPGDGILLNACCPGWVRTDMAGP 238

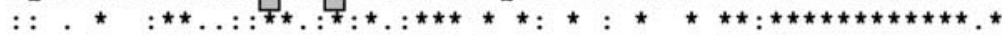

KATKSPEEGAETPVYLALLPPDAEGPHGQFVSEKRVEQW--------- 277 KATKS PEEGAETPVYLALLPPDAEGPHGQFVSEKRVEQW---------- 277 KAPKSPEVGAETPVYLALLPSDAEGPHGQFVTDKKVVEWGVPPESYPWVNA 289 NATKS PEEGAETPVYLALLPPDAEGPHGQFVMDKKVEQW----------- 277 KATKSPEEGAETPVYLALLPPGAEGPHGQFVQDKKVEPW---------- 277 KATKS PEEGAETPVYLALLPPDAEGPHGQFVQDKKVEPW----------- 277 KAPKSPEEGAETPVYLALLPSDADGPHGQFVSEKTVRTW----------- 276 KAPKSPEEGAQTPTYLALLPEGAKEPHGQLVWDKTVQEW----------- 276 KAPKS PEEGAQTPTYLALLPAGAKE PHGQLVWDKVVQEW----------- 276 KAPKS PEEGAETPVYLAMLPEGAKEPHGQLVWDKTVQEW----------- 277

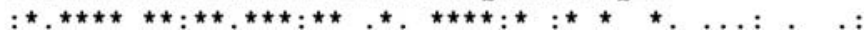

Figure 1 Protein sequence alignment of chicken 20HSD with other known 20HSDs. Putative cosubstrate-binding site AAs 10-34,

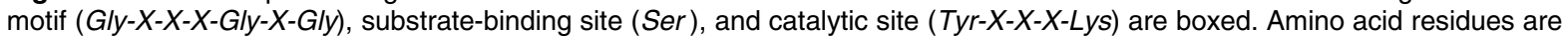
numbered on the right. $\left(^{*}\right)$ All amino acid residues in this column are identical in all sequences in the alignment; $(:)$ conserved substitutions have been observed; (.) semi-conservative substitutions were observed (according to UniProKB/Swiss-Prot). 
Table 1 Protein sequence homology of putative chicken 20HSD sequence with known sequences of other vertebrates expressed in percentage of identical amino acid residues

\begin{tabular}{|c|c|c|c|c|c|c|c|c|c|}
\hline & Zebrafish & Ayu fish & Rainbow trout & Chicken & Mouse & Rat & Rabbit & Pig & Orangutan \\
\hline Human & 61 & 61 & 60 & 78 & 86 & 85 & 83 & 84 & 98 \\
\hline Orangutan & 61 & 61 & 60 & 78 & 86 & 85 & 83 & 84 & $x$ \\
\hline Pig & 58 & 59 & 58 & 73 & 79 & 80 & 78 & $x$ & 84 \\
\hline Rabbit & 60 & 60 & 58 & 72 & 80 & 80 & $\times$ & 78 & 83 \\
\hline Rat & 62 & 63 & 61 & 75 & 89 & $x$ & 80 & 80 & 85 \\
\hline Mouse & 61 & 61 & 60 & 75 & $x$ & 89 & 80 & 79 & 86 \\
\hline Chicken & 64 & 60 & 60 & $\times$ & 75 & 75 & 72 & 73 & 78 \\
\hline Rainbow trout & 81 & 84 & $\times$ & 60 & 60 & 61 & 58 & 58 & 60 \\
\hline Ayu fish & 79 & $x$ & 84 & 60 & 61 & 63 & 60 & 59 & 61 \\
\hline
\end{tabular}

testes, whereas lower expression was detected in other tissues. The single band of a $400 \mathrm{bp}$ amplified fragment was detected in all tissues (not shown) using electrophoretic analysis of the reaction product. The expression of ch20HSD was further compared with

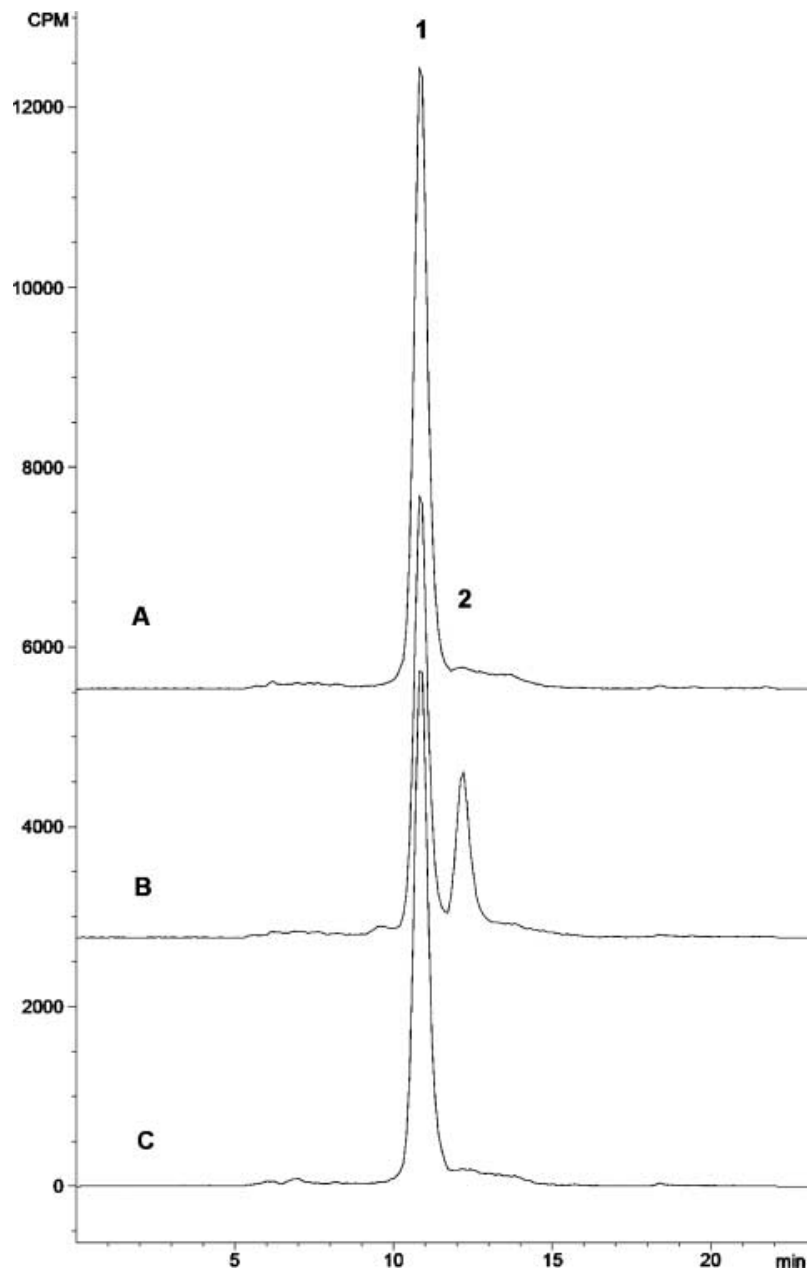

Figure 2 Conversion of corticosterone in $(A)$ non-transfected and (B) transfected $E$. coliwith plasmids $p E T$ SUMO/20HSD and (C) pET SUMO/CAT. 1, Corticosterone and 2, 20-dihydrocorticosterone. the 20-reductase activity of intact tissue slices and tissue homogenates. The incubation of tissue slices with $\left[{ }^{3} \mathrm{H}\right]$ corticosterone revealed 20 -reductase activity in all investigated tissues with the exception of the brain and heart (Fig. 8). A similar pattern was also observed in homogenates. As illustrated in Table 2, the tissue homogenates efficiently reduced corticosterone at $\mathrm{C}_{20}$ in the presence of NADPH but not of NADH.

\section{Discussion}

We have succeeded in cloning chicken 20HSD. The cloned ch20HSD cDNA predicted a protein of 276 amino acid residues that was 13 amino acid residues shorter than the pig protein (Tanaka et al. 1992). Using ch20HSD cDNA, we found that the transfection of E. coli with this cDNA leads to the conversion of corticosterone to 20-dihydrocorticosterone and progesterone to 20-dihydroprogesterone with higher $20 \beta$ HSD than $20 \alpha$ HSD activity. Similarly, $\beta$-epimers of 20-dihydrocorticosterone and 20-dihydroprogesterone were demonstrated as the main products of 20HSD in the duck intestine (DiBattista et al. 1989). In addition, the reduction catalyzed by ch20HSD was cosubstratespecific, required NADPH instead of NADH and apart

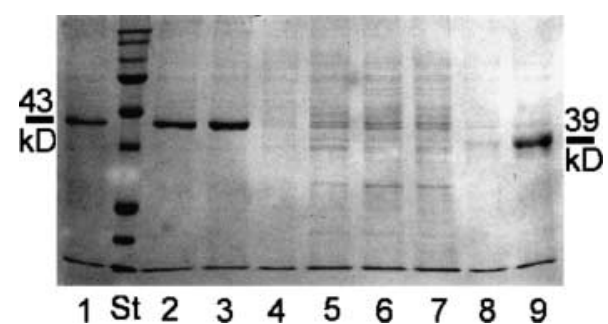

Figure 3 Overexpression and purification of chicken 20HSD. St, molecular mass marker; lanes 1-3, lysate from cells transfected with $\mathrm{pET}$ SUMO/ch20HSD plasmid 3, 5, and $7 \mathrm{~h}$ after induction with IPTG; lanes 4-7, lysate from cells without plasmid 1, 3, 5, and $7 \mathrm{~h}$ after induction with IPTG; and lanes 8 and 9 , lysate from cells transfected with $\mathrm{pET}$ SUMO/CAT plasmid 1 and $5 \mathrm{~h}$ after induction with IPTG. 


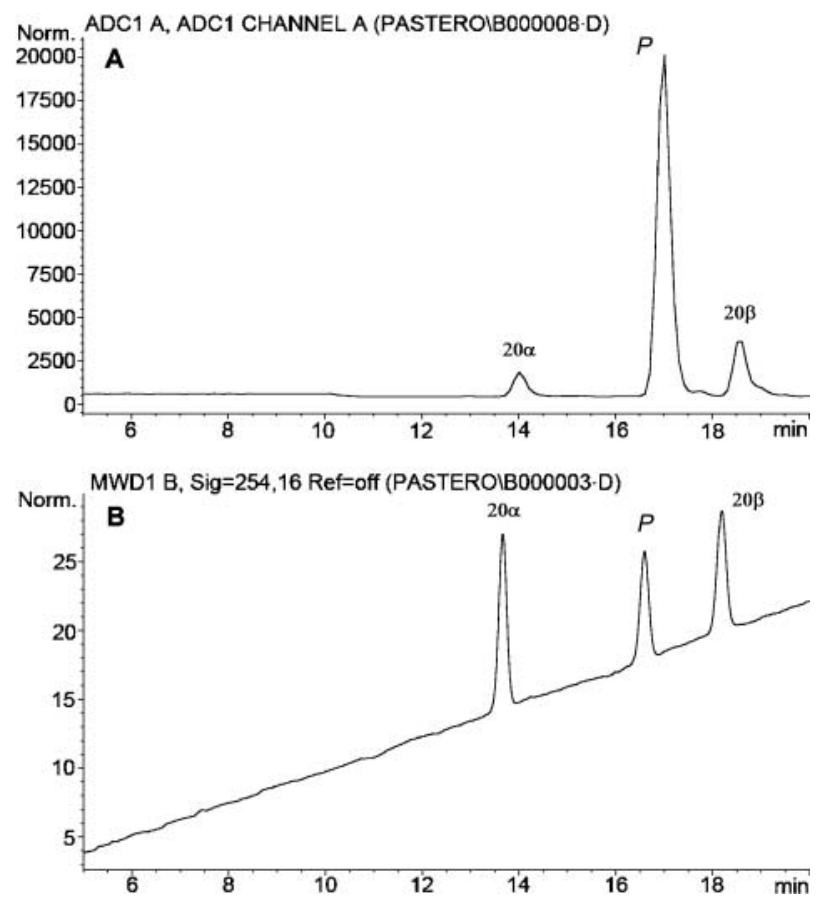

Figure 4 Conversion of progesterone by chicken 20HSD.

(A) Sample (radioactivity detection); (B) standards (u.v. detection). $20 \alpha$, 4-Pregnen-20 $\alpha$-ol-3-one; P, 4-pregnen-3,20-dione; $20 \beta$, 4-pregnen-20ß-ol-3-one.

from 20HSD activity also possessed $3 \alpha-$ and 3 3 HSD activity. Finally, the tissues that expressed ch20HSD mRNA also had 20-reductase activity. The differences in 20-ketosteroid activity and ch20HSD mRNA expression indicate that either mRNA expression does not correlate with active enzyme or that the protein cloned in our experiments is not the only 20HSD operating in some chicken tissues. Comparison of Figs 7 and 8 suggests that ch20HSD plays a smaller role in reduction of 20-ketosteroids in liver, oviduct, ovary, and especially in brain and heart and that additional 20-ketosteroid reductase(s) have to operate in liver and oviduct. This is consistent with previously reported 20HSD activities of mammalian hydroxysteroid dehydrogenases, such as $17 \beta \mathrm{HSD}$ and $3 \alpha \mathrm{HSD}$ (Penning 2003) and discrete tissue distribution of enzymes that possess 3-, 17-, and 20-ketosteroid reductase activities in varying ratios (Penning et al. 2000). We cannot also exclude the role of other carbonyl reductases (Nishinaka et al. 1992, Maser 1995).

The predicted amino acid sequence of ch20HSD revealed high homology to the mammalian 20ßHSD reaching more than $70 \%$ on average. Similar to other steroid dehydrogenases, ch20HSD displays polyfunctional enzyme activity, 3- and 20HSD activity, but in comparison to some other enzymes, it shows an unusual absence of stereochemical specificity as both $3 \alpha / 3 \beta$ and $20 \alpha / 20 \beta$-epimers were identified. In contrast, 20HSD in pigs operates as $3 \alpha / 3 \beta, 20 \beta$ HSD (Ohno et al. 1991) and in Streptomyces hydrogenans only as $3 \alpha, 20 \beta$ HSD (Edwards \& Orr 1978), whereas cyprinid fishes coexpress both $20 \alpha$ - and 20ßHSD activities although it is not known whether these activities reflect one single or two different enzymes (Thibaut \& Porte 2004). However, the results in the present study point to a possibility that ch20HSD has similar widespread distribution as 20ßHSD in fishes and neonatal pigs (Kobayashi et al. 1996, Guan et al. 1999).

The physiological role of 20ßHSDs is not completely clear. These enzymes show high similarity to carbonyl reductases that have been implicated not only in elimination of reactive carbonyl compounds, but also in reduction of biologically active compounds, such as prostaglandins and steroid hormones (Maser 1995). The role of $20 \beta \mathrm{HSD}$ is well documented in oocyte maturation in lower vertebrates, in which $17 \alpha, 20 \beta$ dihydroprogesterone has been proven to be an important maturation-inducing factor (Nagahama 1997).

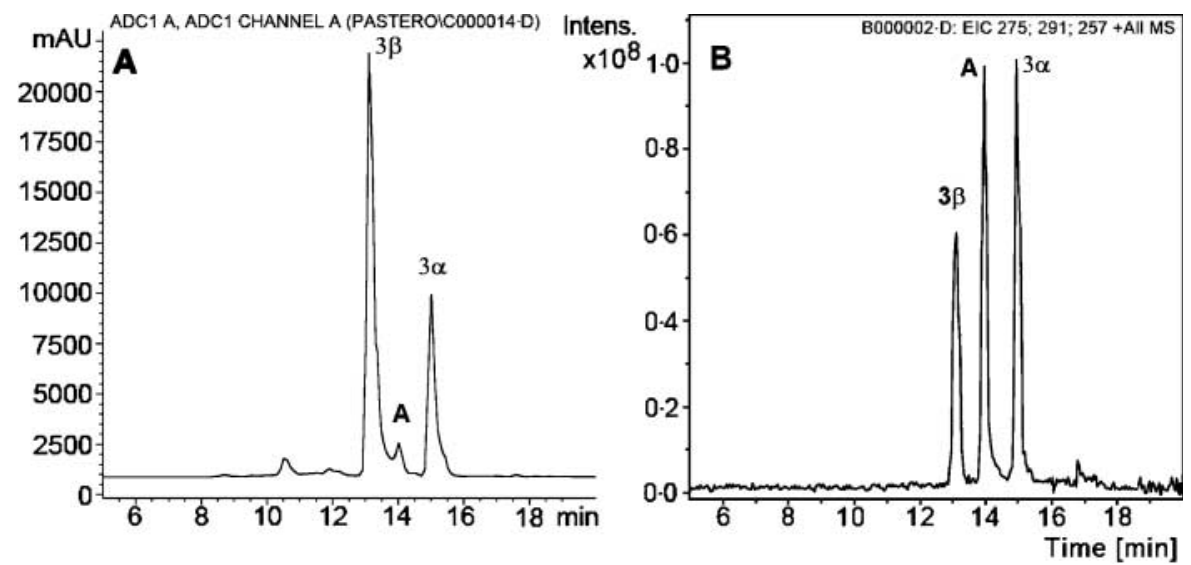

Figure 5 Conversion of androstanolone by chicken 20HSD. (A) Sample (radioactivity detection); (B) standards (MS detection). $3 \beta, 5 \alpha$-androstan-3 $\beta, 17 \beta$-diol; A, $5 \alpha$-androstan-17 $\beta$-ol-3-one; $3 \alpha$, $5 \alpha$-androstan-3 $\alpha, 17 \beta$-diol. 


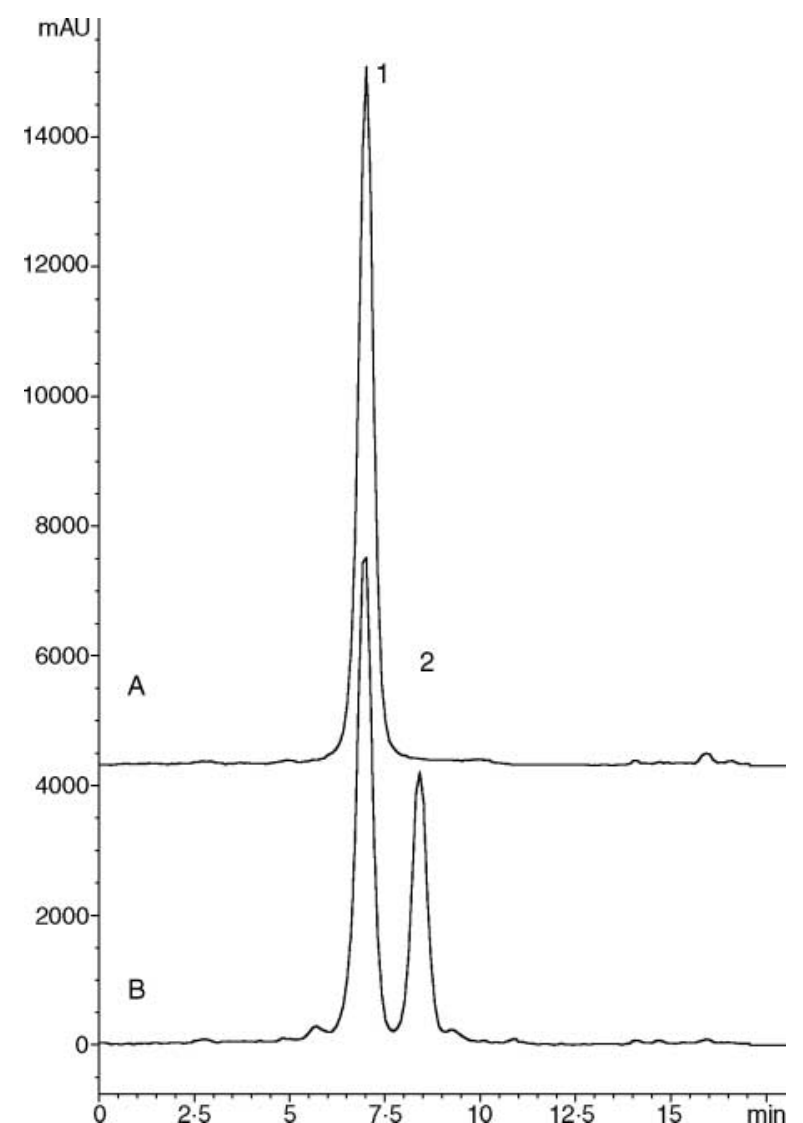

Figure 6 HPLC chromatogram of corticosterone metabolites from enzymatic assay of ch20HSD purified protein overexpressed in E. coli. Metabolism of corticosterone in the presence of (A) NADH and (B) NADPH. 1, corticosterone and 2, 20-dihydrocorticosterone.

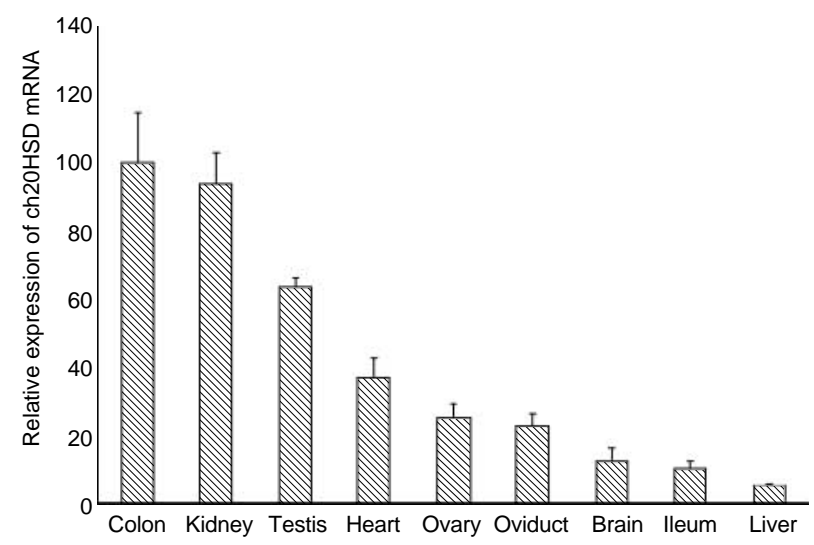

Figure 7 Tissue distribution of 20HSD in chicken. Relative levels of expression of ch20HSD. Colon was normalized to $100 \%$ and compared with other tissues. $\triangle \mathrm{CT}$ values (expressed as mean $\Delta \mathrm{CT}=\mathrm{CT}$ of the $20 \mathrm{HSD}$ gene $-\mathrm{CT}$ of the $\beta$-actin) were: colon, $3.2 \pm 0.2$; kidney, $2 \cdot 7 \pm 0.2$; testis $3.3 \pm 0 \cdot 1$; heart $3.7 \pm 0.2$; ovary, $4.9 \pm 0 \cdot 4$; oviduct, $4 \cdot 7 \pm 0 \cdot 1$; brain, $5 \cdot 6 \pm 0 \cdot 3$; ileum, $6 \cdot 1 \pm 0.3$; and liver, $6 \cdot 5 \pm 0 \cdot 2$. The ch20HSD mRNA abundances in oviduct were measured in chicks treated with DES (for further details, see Materials and methods). Values are means \pm S.E.M. of seven animals.

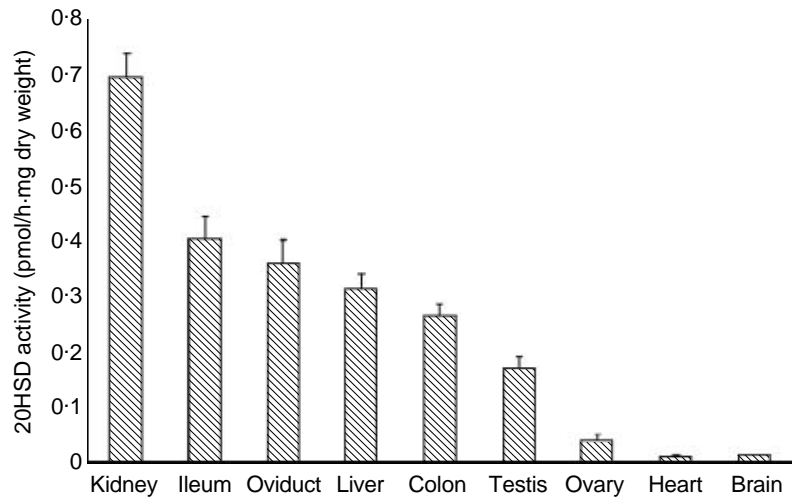

Figure 8 Reduction of corticosterone to 20-dihydrocorticosterone and 11-dehydro-20-dihydrocorticosterone in tissue slices. The 20-reductase activities in oviduct were measured in chicks treated with DES (for further details, see Materials and methods). Values are means \pm S.E.M. of 9-12 animals.

This steroid is synthesized from $17 \alpha$-hydroxyprogesterone by $20 \beta \mathrm{HSD}$ in the follicular layers of the ovaries. Similarly, 20ßHSD seems to be also involved in the regulation of spermatogenesis in fishes (Sakai et al. 1989). In mammals, 20-ketosteroid reductases are generally considered to play a role in progesterone activity. First, they protect against the occupancy of progesterone receptors by inappropriate ligands, because 20-reduction considerably decreases progestin potency. Second, they are able to prevent the conversion of $\mathrm{C}_{21}$ to $\mathrm{C}_{19}$ steroids, because the conversion of progesterone to 20-dihydroprogesterone prevents 17,20 -lyase from producing the precursors to $\mathrm{C}_{19}$ sex hormones. Several enzymes responsible for this reaction were found and it was shown that they have predominantly 20 $\alpha$-stereospecificity (Penning 1997, Bumke-Vogt et al. 2002). 20ß-Stereospecificity was identified in testes of neonatal pigs (Nakajin et al. 1988a), where it seems to regulate steroid hormone concentration in the testes during development. However, later studies revealed a

Table 2 Cosubstrate dependence of activity of 20HSD in tissue homogenates

NIL

Tissue

Kidney

Liver

Colon

Ileum

Heart

Brain

0
0
0
0
0
0
0

Oviduct

+ NADPH

+ NADH

Values are means \pm S.E.M. of six animals. Data are given in picomole of corticosterone reduced to 20 -dihydrocorticosterone plus 11 -dehydro20-dihydrocorticosterone per hour and milligram of protein. The 20-reductase activity in oviduct homogenates was measured in chicks treated with DES (for further details, see Materials and methods). 
widespread distribution of 20ßHSD in neonatal pigs, which suggest a broader role for this enzyme in steroid hormone metabolism than merely in the synthesis of androgens in testicular cells (Kobayashi et al. 1996). The substrate specificity of pig $20 \beta \mathrm{HSD}$ is not identical to ch20HSD. Although pig $20 \beta$ HSD catalyzes the reduction of progesterone, it does not reduce 11-oxo/11-hydroxy$\mathrm{C}_{21}$ steroids, such as cortisol, corticosterone, and cortisone (Nakajin et al. 1988a).

Presently, it is not known whether ch20HSD exhibits some of the physiological roles described herein. However, recent experiments in our laboratory have shown its significance in mineralocorticoid target tissues (Mazancová et al. 2005). In these tissues, such as kidney and intestine, ch20HSD together with $11 \beta H S D$ might play a role in preventing corticosterone from binding to the mineralocorticoid receptors. Previous studies showed that avian mineralocorticoid receptors bind aldosterone and corticosterone with nearly equal affinities (Rafestin-Oblin et al. 1989, Sandor et al. 1989) and reduction of corticosterone to 20-dihydrocorticosterone might be an alternative system to $11 \beta$-oxidation to facilitate aldosterone binding. 20-Dihydrocorticosterone has much lower affinity to mineralocorticoid receptor than corticosterone (DiBattista et al. 1989) and in contrast with corticosterone, it is not able to induce electrogenic $\mathrm{Na}^{+}$transport usually regulated by aldosterone (Mazancová et al. 2005). In addition, the functional coupling of $11 \beta$ oxidation followed by reduction of the ketone group at position $\mathrm{C}_{20}$ via cosubstrates might amplify the effect of steroid dehydrogenases (Mercer \& Krozowski 1992). Similarly, the expression of ch20HSD in reproductive organs might modulate steroid synthesis via cytochrome $\mathrm{P}^{4} 50_{\mathrm{C} 17}$ because $20 \beta$-hydroxy-C $\mathrm{C}_{21}$ steroids have been shown to inhibit $\mathrm{P}^{4} 50_{\mathrm{C} 17}$ (Nakajin et al. $1988 b$ ) and this cytochrome is expressed in both avian gonadal and non-gonadal tissues (Boswell et al. 1995, Schlinger et al. 1999).

In summary, it is well known that steroid hormone receptors demonstrate considerable promiscuity in binding various steroid ligands. Therefore, the reduction of a potent steroid hormone into less potent or inactive derivatives might be an alternative system to the well-known $11 \beta \mathrm{HSD}$ pre-receptor modulation of steroid activity or might modulate the concentration of $\mathrm{C}_{19}$ hormones in gonadal and extragonadal tissues. The advantage of 20HSD compared with $11 \beta \mathrm{HSD}$ is that this enzyme might

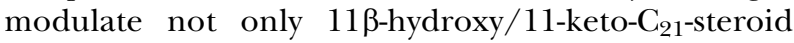
hormones but also progesterone and sex hormones. The detailed role of this enzyme in various tissues remains to be determined, but the availability of chicken 20HSD cDNA offers an opportunity for further studies.

\section{Acknowledgements}

This work was supported by the Academy of Sciences of the Czech Republic (grant nos IAA 6011201 and AVOZ 501 10509) and Charles University grant no. 216/2004. We would like to thank Miss I Mezteková and Mrs I Muricová for their skilful technical assistance. The authors declare that there is no conflict of interest that would prejudice the impartiality of this scientific work.

\section{References}

Agarwal AK, Tusle-Luna M-T, Monder C \& White PC 1990 Expression of 11 $\beta$-hydroxysteroid dehydrogenase using recombinant vaccinia virus. Molecular Endocrinology 4 1827-1832.

Boswell T, Hall MR \& Goldsmith AR 1995 Testosterone is secreted extragonadally by European quail maintained on short days. Physiological Zoology 68 967-984.

Bumke-Vogt C, Bähr V, Diederich S, Herrmann SM, Anagnostopoulos I, Oelkers W \& Quinkler M 2002 Expression of the progesterone receptor and progesterone-metabolising enzymes in the female and male human kidney. Journal of Endocrinology 175 349-364.

Dougherty DC \& Sanders MM 2005 Estrogen action: revitalization of the chick oviduct model. Trends in Endocrinology and Metabolism 16 414-419.

DiBattista JA, Mehdi AZ \& Sandor T 1989 Steroid C-20 oxidoreductase activity of duck intestinal mucosa: the interrelations of the enzymatic activity with steroid binding. General and Comparative Endocrinology 74 136-147.

Edwards CA \& Orr JC 1978 Comparison of the $3 \alpha$-and $20 \beta$ hydroxysteroid dehydrogenase activities of the cortisone reductase of Streptomyces hydrogenans. Biochemistry 17 4370-4376.

Guan G, Tanaka M, Todo T, Young G, Yoshikuni M \& Nagahama Y 1999 Cloning and expression of two carbonyl reductase-like $20 \beta$ hydroxysteroid dehydrogenase cDNAs in ovarian follicles of rainbow trout (Oncorhynchus mykiss). Biochemical and Biophysical Research Communications 255 123-128.

Jörnvall H, Persson B, Krook M, Atrian S, Gonzalez-Duarte R, Jeffery J \& Ghosh D 1995 Short-chain dehydrogenases/reductases (SDR). Biochemistry 34 6003-6013.

Kobayashi K, Ohno S, Shinoda M, Toyoshima S \& Nakajin S 1996 Immunochemical distribution and immunohistochemical localization of 20ß-hydroxysteroid dehydrogenase in neonatal pig tissues. Journal of Steroid Biochemistry and Molecular Biology $\mathbf{5 9}$ 485-493.

Maser E 1995 Xenobiotic carbonyl reduction and physiological steroid oxidoreduction. The pluripotency of several hydroxysteroid dehydrogenases. Biochemical Pharmacology 49 421-440.

Mazancová K, Kučka M, Mikšík I \& Pácha J 2005 Glucocorticoid metabolism and $\mathrm{Na}^{+}$transport in chicken intestine. Journal of Experimental Zoology 303A 113-122.

Mercer WR \& Krozowski ZS 1992 Localization of an 11ß-hydroxysteroid dehydrogenase activity to the distal nephron. Evidence for the existence of two species of dehydrogenase in the rat kidney. Endocrinology 130 540-543.

Nagahama Y 1997 17 $\alpha$ /20 $\beta$-Dihydroxy-4-pregnen-3-one, a maturationinducing hormone in fish oocytes: mechanisms of synthesis and action. Steroids 62 190-196.

Nagahama Y \& Adachi S 1985 Identification of maturation-inducing steroid in a teleost, the amago salmon (Oncorhynchus rhodurus). Developmental Biology 109 428-435.

Nakajin S, Ohno S \& Shinoda M 1988a 20ß-hydroxysteroid dehydrogenase of neonatal pig testis: purification and some properties. Journal of Biochemistry 104 565-569. 
Nakajin S, Takahashi K \& Shinoda M $1988 b$ Inhibitory effects and spectral changes on pig testicular cytochrome P-450 (17 $\alpha$-hydroxylase/lyase) by 20ß-hydroxy-C ${ }_{21}$-steroids. Yakugaku Zasshi 108 $1188-1195$

Nishinaka T, Kinoshita Y, Terada N, Terada T, Mizoguchi T \& Nishihara T 1992 Characterization of multiple forms of carbonyl reductase from chicken liver. Enzyme 46 221-228.

Ohno S, Nakajin S \& Shinoda M 1991 20ß-Hydroxysteroid dehydrogenase of neonatal pig testis: $3 \alpha / \beta$-hydroxysteroid dehydrogenase activities catalyzed by highly purified enzyme. Journal of Steroid Biochemistry and Molecular Biology 38 787-794.

Ohno S, Nakajin S \& Shinoda M 1992 Ontogeny of testicular steroid dehydrogenase enzymes in pig $(3 \alpha / \beta-, 20 \alpha$ - and $20 \beta-)$. Evidence for two forms of $3 \alpha / \beta$ hydroxysteroid dehydrogenase. Journal of Steroid Biochemistry and Molecular Biology 42 17-21.

Penning TM 1997 Molecular endocrinology of hydroxysteroid dehydrogenases. Endocrine Reviews 18 281-305.

Penning TM 2003 Hydroxysteroid dehydrogenases and pre-receptor regulation of steroid hormone action. Human Reproduction Update 9 193-205.

Penning TM, Burczynski ME, JezJM, Hung CF, Lin HK, Ma H, Moore M, Palackal N \& Ratnam K 2000 Human 3 $\alpha$-hydroxysteroid dehydrogenase isoforms (AKR1C1-AKR1C4) of the aldo-keto reductase superfamily: functional plasticity and tissue distribution reveals roles in the inactivation and formation of male and female sex hormones. Biochemical Journal $35167-77$.

Quinkler M, Johanssen S, Grossmann C, Bähr V, Müller M, Oelkers W \& Diederich S 1999 Progesterone metabolism in the human kidney and inhibition of 11ß-hydroxysteroid dehydrogenase type 2 by progesterone and its metabolites. Journal of Clinical Endocrinology and Metabolism 84 4165-4171.
Rafestin-Oblin ME, Couette B, Radanyi C, Lombes M \& Baulieu EE 1989 Mineralocorticoid receptor of the chick intestine. Oligomeric structure and transformation. Journal of Biological Chemistry 264 9304-9309.

Sakai N, Ueda H, Suzuki N \& Nagahama Y 1989 Steroid production by amago salmon (Oncorhynchus rhodurus) testes at different development stages. General and Comparative Endocrinology 75 231-240.

Sandor T, Skadhauge E, DiBattista JA \& Mehdi AZ 1989 Interrelationships of the intestinal glucocorticoid and mineralocorticoid receptor systems with salt homeostasis. In Progress in Avian Osmoregulation, pp 305-332. Eds MR Hughes \& A Chadwick. Leeds: Leeds Philosophical and Literary Society.

Schlinger BA, Lane NI, Grisham W \& Thompson L 1999 Androgen synthesis in a songbird: a study of cyp 17 (17 $\alpha$-hydroxylase/ C17,20-lyase) activity in the zebra finch. General and Comparative Endocrinology 113 46-58.

Tanaka M, Ohno S, Adachi S, Nakajin S, Shinoda M \& Nagahama Y 1992 Pig testicular 20ß-hydroxysteroid dehydrogenase exhibits carbonyl reductase-like structure and activity. Journal of Biological Chemistry 267 13451-13455.

Thibaut R \& Porte C 2004 Effects of endocrine disrupters on sex steroid synthesis and metabolism pathways in fish. Journal of Steroid Biochemistry and Molecular Biology 92 485-494.

Vylitová M, Mikšík I \& Pácha J 1998 Metabolism of corticosterone in mammalian and avian intestine. General and Comparative Endocrinology 109 315-324.

Received 16 June 2006

Accepted 8 August 2006

Made available online as an Accepted Preprint 7 September 2006 